\title{
Quantitative Analysis of Plasticizers in a Wastewater Treatment Plant: Influence of the Suspended Solids Parameter
}

\author{
Nathália C. Viecelli, Eduardo R. Lovatel, Eduardo M. Cardoso and Irajá Nascimento Filho* \\ Centro de Ciências Exatas e Tecnológicas, Instituto de Saneamento Ambiental, \\ Universidade de Caxias do Sul, Rua Francisco Getúlio Vargas, 1130, \\ 95070-560 Caxias do Sul-RS, Brazil
}

\begin{abstract}
A ocorrência de ftalato de di(2-etilhexila) (DEHP) e bisfenol A (BPA) em águas residuais da estação de tratamento da Universidade de Caxias do sul (ETE-UCS) foi investigada neste trabalho. Durante cinco meses, cinco amostras dos pontos de entrada e saída da ETE-UCS foram coletadas e submetidas à extração líquido-líquido (LLE). Os extratos orgânicos foram analisados por cromatografia a gás com detecção por ionização em chama (GC/FID). As eficiências de remoção da ETE-UCS foram de 37,79 e 19,90\% para BPA e DEHP, respectivamente. As concentrações médias no ponto de saída foram 52,52 e $20,00 \mathrm{mg} \mathrm{L}^{-1}$ para BPA e DEHP, respectivamente. As concentrações altas dos analitos, no ponto de saída da ETE podem estar relacionadas com a remoção baixa dos sólidos suspensos das amostras brutas. Para confirmar esta hipótese, outras cinco amostras dos pontos de entrada e saída da ETE-UCS também foram submetidas à LLE, com e sem o procedimento de pré-filtração. A remoção de DEHP foi de 74,44\% sendo a concentração média no ponto de saída de $6,01 \mathrm{mg} \mathrm{L}^{-1}$. Para as amostras não pré-filtradas a remoção de DEHP foi de 40,96\% sendo a concentração média no ponto de saída de $17,04 \mathrm{mg} \mathrm{L}^{-1}$.
\end{abstract}

This study investigated the occurrence of di(2-ethylhexyl)phthalate (DEHP) and bisphenol A (BPA) in the wastewater treatment plant of the University of Caxias do Sul (WWTP-UCS). During five months, five wastewater samples from the inflow and outflow points were collected and submitted to liquid-liquid extraction (LLE). The organic extracts were analyzed by gas chromatography with flame ionization detection (GC/FID). The removals grades were 37.79 and $19.90 \%$ for BPA and DEHP, respectively. The average concentrations at the outflow points were 52.52, and $20.00 \mathrm{mg} \mathrm{L}^{-1}$, for BPA and DEHP, respectively. These high target compound contents at the exit point may be due to the low removal of suspended solids from the raw samples (only $42.72 \%$ removal). To confirm this hypothesis, other five samples also from the inflow and out flow points were submitted to LLE extraction with and without the prefiltration step. The DEHP removal in the filtered samples was $74.44 \%$ and the median DEHP concentration at the outflow point was $6.01 \mathrm{mg} \mathrm{L}^{-1}$. For the unfiltered samples, the DEHP removal was $40.96 \%$ and the median DEHP concentration at the outflow point was $17.04 \mathrm{mg} \mathrm{L}^{-1}$.

Keywords: liquid residues, gas chromatography, bisphenol A, di(2-ethylhexyl)phthalate

\section{Introduction}

Plasticizers are organic compounds added to polymers to facilitate processing and increase flexibility and toughness of the final product by internal modification of the polymer molecule. Phthalates, including DEHP, are a family of plasticizers and dominate polymer production.

DEHP can interfere in the functioning of the endocrine system and in the mechanism of hormone action. Endocrine deregulators or endocrine disruptors may cause reproductive

\footnotetext{
*e-mail: inascimf@ucs.br
}

anomalies (morphological and functional gonadal dysfunction, infertility and decreased libido) and congenital malformations. ${ }^{1-3}$ Bornehag et al..$^{4}$ reported associations between dust concentrations of specific phthalate esters in house dust and asthma, rhinitis, and eczema in children. Phthalate esters were also detected in the serum of young Puerto Rican girls with premature breast development. ${ }^{5}$ The long term exposure to high concentrations of DEHP can damage the liver and testicles, in mammals and cause death in aquatic species. Plasticizers can also influence the mobility and bioavailability of toxic substances such as polychlorinated biphenyls and metal ions by changes in 
their water or lipid solubility. ${ }^{6}$ As plasticizers are used in packaging, clothing, films, paints, adhesives, cosmetics, ink printers and many other products, they are widespread in virtually all environments. DEHP was also detected in mineral, ultra pure and tap waters, ${ }^{7}$ municipal solid waste compost, ${ }^{8}$ sewage and wastewater treatment sludge, ${ }^{9}$ river sediments, ${ }^{6}$ landfill leachate ${ }^{10,11}$ and swine slaughterhouse wastewaters. ${ }^{12}$

Bisphenol A (BPA), 4,4'-(1-methylethylidene)bisphenol, is widely employed as a monomer in the production of polycarbonate and some epoxy resins ${ }^{13}$ that are commonly employed as adhesives and cover materials. BPA improves some physical properties of polymeric materials, such as resistance, hardness, and thermal stability. BPA is an antioxidant highly resistant to chemical degradation and its environmental persistence may be due to the low vapor pressure and relatively low octanol-water partitioning coefficient. Under anaerobic conditions, BPA can be considered non biodegradable. ${ }^{14}$ BPA can interact with humans and wildlife and cause adverse effects. Among the examples of these adverse effects are the formation of additional female organs, enlarged accessory sex glands, morphological and functional gonadal dysfunction and interference in the functioning of the endocrine system. ${ }^{1,2,7,15-18}$ Recently, Zalko et al. ${ }^{19}$ stated that BPA is readily absorbed and metabolized by the skin. The transdermal route is expected to contribute substantially to BPA exposure in human, when direct contact with BPA (free monomer) occurs. Braun et al. ${ }^{20}$ had evaluated the variability and predictors of urinary BPA concentrations during pregnancy. According to the authors, by occupation, cashiers had the highest BPA concentrations (geometric mean: $\left.2.8 \mu \mathrm{g} \mathrm{g}^{-1}\right)$. Consuming canned vegetables at least once a day was associated with higher BPA concentrations (geometric mean: $2.3 \mu \mathrm{g} \mathrm{g}^{-1}$ ) compared to those consuming no canned vegetables (geometric mean $1.6 \mu \mathrm{g} \mathrm{g}^{-1}$ ). High molecular weight phthalate in urine and tobacco smoke metabolite in serum concentrations were positively associated with BPA concentrations.

Most of the plasticizers that enter the treatment plants are adsorbed by the waste sludge and biodegraded. ${ }^{21}$ On the other hand, the plasticizers remaining in the aqueous phase are much less biodegraded. Thus, these compounds can persist in the environment and contaminate superficial and groundwater.

There are many studies reporting the removal of plasticizers from wastewaters. ${ }^{22-25}$ Due to its physicochemical characteristics such as water solubility and octanol-water partitioning coeficent, DEHP and BPA (in a less extent) must be highly adsorbed in the parculate matter, in wastewaters. Thus, the removal of suspended solids seems to be the main parameter monitoring when the removal of DEHP and BPA is focused.

However, as far as we know, no investigation of the influence of the suspended solids parameter in the removal efficiency of plasticizers from wastewaters has been found in the literature. In order to study this influence, the experimental procedures were divided into two sections. In the first one, five wastewater samples from the inflow and outflow points were collected for five months and submitted to LLE and the instrumental analysis was performed by GC/ FID. In the second one, other five samples from the inflow and outflow points were submitted to LLE with and without the pre-filtration step, and also analyzed by GC/FID.

\section{Experimental}

\section{Samples and materials}

The WWTP-UCS treats around $100 \mathrm{~m}^{3} \mathrm{~d}^{-1}$ of wastewater generated at the university ( $c a$. 20,000 people). The treatment system comprises an aeration lagoon (hydraulic residence time: $4 \mathrm{~d}$ ), a sedimentation lagoon (hydraulic residence time: $2 \mathrm{~d}$ ) and two maturation lagoons (total hydraulic residence time: $26.9 \mathrm{~d}$ ). In the first experimental section, the wastewater samples were collected once a month (from December 2008 to April 2009) from the inflow and outflow points of the WWTP-UCS located in Caxias do Sul, Rio Grande do Sul, Southern Brazil, in glass bottles (1 L capacity) with caps protected by aluminum foil to prevent contamination. The sampling period was from 8:00 am to 6:00 pm, every $2 \mathrm{~h}$. The total volume was of $6 \mathrm{~L}$. All the samples were mixed and $1 \mathrm{~L}$ sample was collected from the mixture (composite sample). Figure 1 shows the sampling points in the WWTP-UCS.

The samples were maintained at $4{ }^{\circ} \mathrm{C}$ and protected from light until the extraction procedures were performed

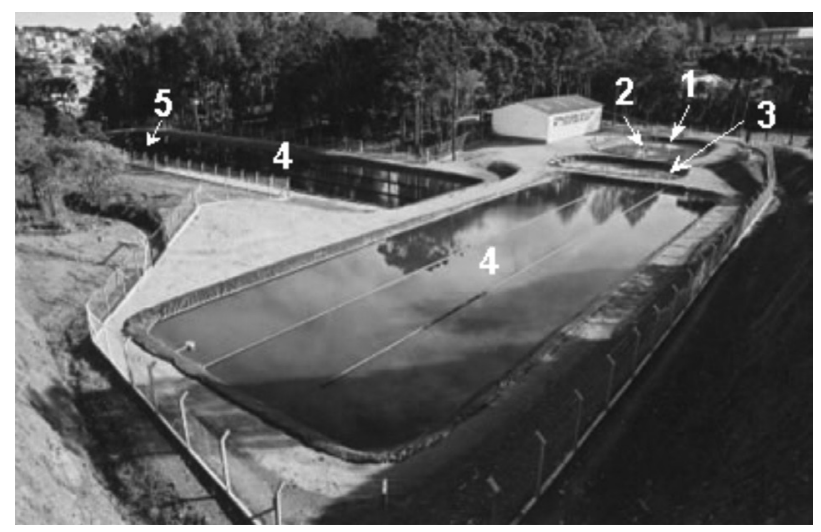

Figure 1. Wastewater treatment plant. 1: Aeration lagoon (inflow), 2: sampling point (inflow), 3: sedimentation lagoon, 4: maturation lagoons, 5: sampling point (outflow). 
at most $24 \mathrm{~h}$ after the collection. The same procedures were adopted for other five wastewater samples collected once a month (from March 2009 to July 2010) for the second experimental section. All solvents and reagents were of analytical grade and the solvents were distilled twice in glass apparatus. All glass materials were washed with $n$-hexane, acetone and dichloromethane and dried at $120^{\circ} \mathrm{C}$ for $4 \mathrm{~h}$. Plastic or rubber materials were not used to avoid contact with samples or solvents.

\section{Sample extraction}

For the first experimental section, aliquots of $100 \mathrm{~mL}$ of the composite samples were filtered through a $0.45 \mu \mathrm{m}$ fiberglass mesh filter. After this, hydrochloric acid was added until $\mathrm{pH}$ ca. 2.0. The samples were then extracted three times with $n$-hexane $(20 \mathrm{~mL})$ by shaking for $5 \mathrm{~min}$. The combined extracts were dried with anhydrous sodium sulfate and evaporated to $1.0 \mathrm{~mL}$. For the second experimental section, the samples were divided into two $100 \mathrm{~mL}$ aliquots and submitted to the same extraction procedures as described above, except that the second aliquot was not pre-filtered. The extracts of both experimental sections were analyzed by GC/FID. During the entire experimental period, extraction blanks were analyzed by GC/FID and peaks of the target compounds were not detected.

\section{Instrumental analysis}

A PerkinElmer gas chromatograph, model Autosystem XL (Massachusetts, USA), with a flame ionization detector was used for identification of the target compounds by comparison of the retention times of the samples peaks and the standard compounds (> 90\% purity, Merck Co., Rio de Janeiro, Brazil). The quantification was done by the internal normalization method. An Elite-5 (Massachusetts, USA) fused silica capillary column $(30 \mathrm{~m} \times 0.25 \mathrm{~mm}$ i.d. crossbond 5\% diphenyl-95\% dimethyl polysiloxane, $0.25 \mu \mathrm{m}$ film thickness) was used for the GC separation employing the following oven temperature program: $150{ }^{\circ} \mathrm{C}(5 \mathrm{~min}$ hold) heating to $220^{\circ} \mathrm{C}$ at $3{ }^{\circ} \mathrm{C} \mathrm{min}-1$ and heating to $300{ }^{\circ} \mathrm{C}$ at $10{ }^{\circ} \mathrm{C} \min ^{-1}$ (5 min hold). The injector and detector temperatures were 250 and $300{ }^{\circ} \mathrm{C}$, respectively. The injection volume was $1.0 \mu \mathrm{L}(\mathrm{n}=3)$ in the split mode $(1: 50)$.

\section{Recovery grade and detection limit}

For the first experimental section, the recovery yields of DEHP and BPA were measured by the extraction of real samples spiked with a standard solution (net concentration of the target compounds of $20 \mathrm{mg} \mathrm{L}^{-1}$ ). For the second experimental section the recovery grade of DEHP (standard solution of $20 \mathrm{~m} \mathrm{~L}^{-1}$ ) was measured in the same way. The detection limit was evaluated by successive dilutions of the standard solutions $\left(100 \mathrm{mg} \mathrm{L}^{-1}\right)$.

\section{Results and Discussion}

\section{First experimental section}

The detection limit of DEHP was $0.5 \mathrm{mg} \mathrm{L}^{-1}$ and the detector response was linear between 0.5 and $25 \mathrm{mg} \mathrm{L}^{-1}$ $(r=0.913$; equation: $y=0.424 x-0.078)$. For BPA, the detection limit was $0.02 \mathrm{mg} \mathrm{L}^{-1}$ and the detector response was linear between 0.05 and $1.0 \mathrm{mg} \mathrm{L}^{-1}(\mathrm{r}=0.96$; equation: $y=2.296 x-0.765)$. Figure 2 shows the concentrations of the target compounds at the inflow and outflow points of the WWTP-UCS.
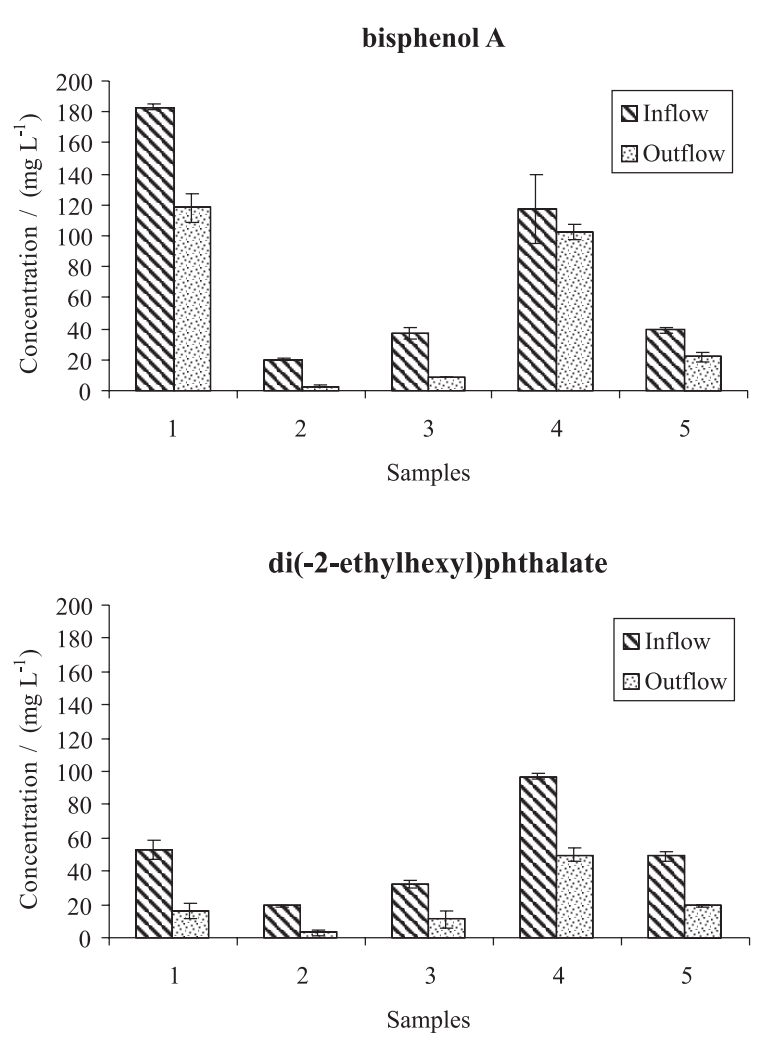

Figure 2. Concentrations of the target compounds at the inflow and outflow points. Error bars represent \pm standard deviations.

The results shown in Figure 2 suggest that the biological treatment employed in the WWTP-UCS does not remove the target compounds efficiently. Figure 3 shows the removal rates of the target compounds.

These low removal rates may be due to some physicochemical characteristics of the target compounds (Table 1). Since BPA and DEHP have low vapor pressures ${ }^{26,27}$ losses by evaporation were ruled out. 


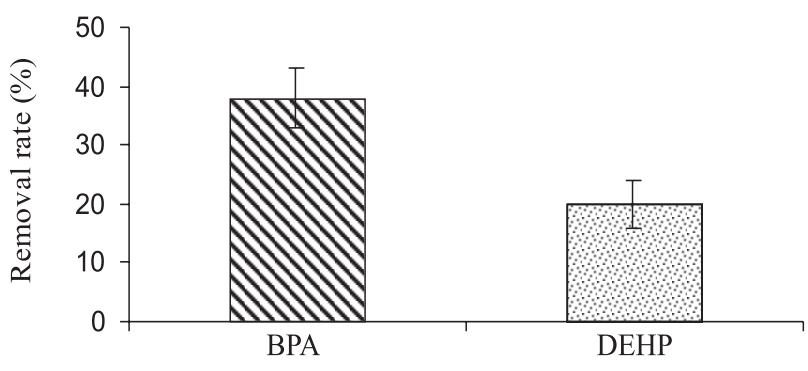

Figure 3. Removal rate of the target compounds. Error bars represent \pm standard deviations.

DEHP present the lowest water solubility. Therefore, high adsorption of this compound to the surface of the suspended solid particles and organic matter must be expected. Marttinen et al. ${ }^{28}$ had studied the sorption of DEHP to different particle size fractions in sewage by serial membrane filtration. Most of the DEHP (71-84\%) was attached to the $0.1-41 \mu \mathrm{m}$ particles and approximately $10-27 \%$ of the DEHP was sorbed on particles larger than $41 \mu \mathrm{m}$. Less than $6 \%$ of the DEHP was in the fraction below $0.1 \mu \mathrm{m}$ and readily available for microbial degradation.

Table 2 shows the physicochemical characteristics of the samples analyzed in the present work.

The COD and BOD removals were relatively high ( 88.17 and $86.70 \%$, respectively). On the other hand, the suspended solids remain high at the outflow point (only $42.72 \%$ removal). These samples characteristics can enhance the DEHP partitioning in the suspended solids and explain the high median concentration of these compounds at the outflow point. The total concentration of hydrophobic contaminants is normally higher in samples with a higher suspended solids content. ${ }^{28}$ This trend is confirmed by the data in Figure 4.

The highest concentrations of the target compounds were detected when the suspended solids parameter was

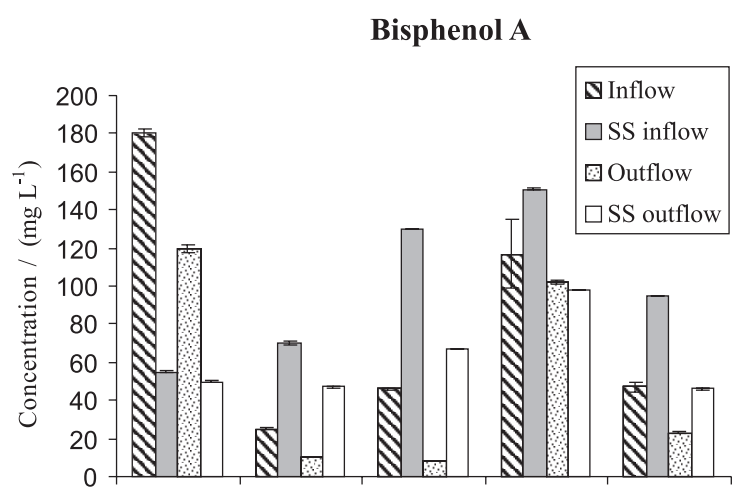

di (-2-ethylhexyl) phthalate

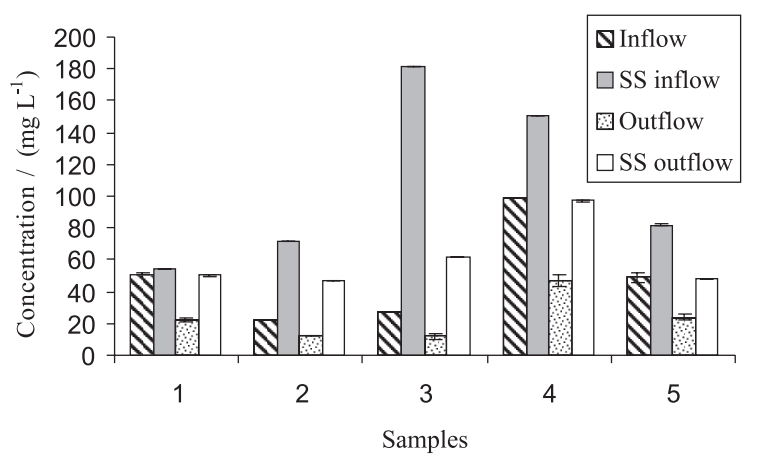

Figure 4. Relationship among the concentrations of the target compounds and the suspended solids parameter. Error bars represent \pm standard deviations.

Table 1. Physicochemical characteristics of the target compounds

\begin{tabular}{lccccc}
\hline Compound & $\log K_{\mathrm{OW}}$ & Molar mass $/\left(\mathrm{g} \mathrm{mol}^{-1}\right)$ & Vapor pressure / Pa & Solubility in water / $\left(\mathrm{mg} \mathrm{L}^{-1}\right)$ & Reference \\
\hline BPA & 3.4 & 228.29 & $5.3 \times 10^{-6}$ & $120-300$ & 26 \\
DEHP & 5.22 & 390.56 & $5.47 \times 10^{-4}$ & 0.041 & 27 \\
\hline
\end{tabular}

Table 2. Physicochemical characteristics of the samples ( $\mathrm{m} \mathrm{L}^{-1}$ when applicable)

\begin{tabular}{|c|c|c|c|c|c|c|}
\hline \multirow[b]{2}{*}{ Inflow } & \multicolumn{5}{|c|}{ Sample } & \multirow[b]{2}{*}{ Average } \\
\hline & 1 & 2 & 3 & 4 & 5 & \\
\hline$\overline{\mathrm{COD} *}$ & 612 & 632 & 1879 & 610 & 282 & 803 \\
\hline BOD** & 433 & 407 & 784 & 389 & 137 & 430 \\
\hline Suspended Solids & 63 & 71 & 136 & 153 & 92 & 103 \\
\hline $\mathrm{pH}$ & 8.3 & 7.9 & 7.9 & 6.4 & 6.9 & 7.5 \\
\hline Outflow & 1 & 2 & 3 & 4 & 5 & Average \\
\hline $\mathrm{COD}$ & 72 & 44 & 111 & 99 & 149 & 95 \\
\hline BOD & 51 & 62 & 82 & 57 & 34 & 57.2 \\
\hline Suspended Solids & 51 & 44 & 56 & 99 & 45 & 59 \\
\hline $\mathrm{pH}$ & 7.1 & 7.0 & 6.9 & 7.8 & 8.2 & 7.4 \\
\hline
\end{tabular}

*Chemical oxygen demand. **Biochemical oxygen demand. 
also higher, except for BPA. The suspended solids in water can form colloidal suspensions with strong electrostatic interactions. Colloidal particles often carry an electrical charge and therefore attract or repel each other. The charge of both the continuous and the dispersed phase, as well as phase mobility are factors affecting this interaction. The chemical structures of the target compounds (Figure 5) can explain the strong contaminant-colloid particle interaction.<smiles>CC(C)(c1ccc(O)cc1)c1ccc(Br)cc1</smiles>

Bisphenol A

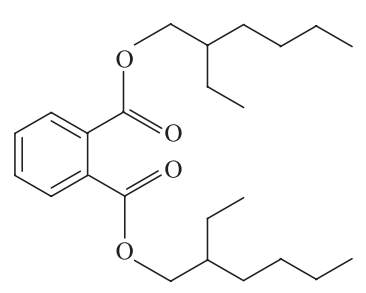

Di(2-ethylhexyl)phthalate
Figure 5. Chemical structures of the target compounds.

The hydroxyl groups in the BPA structure can undergo hydrogen bonding with the water molecules. In this way, chemical interactions among BPA molecules and colloid particles are not feasible. On the other hand, DEHP have a less polar structure and low possibility of forming hydrogen bonds with water. In this way, the adsorption to the colloid particles by electrostatic interaction is favored.

Sorption to suspended solids may vary considerably according to the specific solid and the concentration of chemicals. Thus, the correlations between plasticizer concentrations and suspended solids at the end-point of treatment in the plants are not linear. ${ }^{28-31}$ However, a positive relationship among higher plasticizer concentrations and higher suspended solids content can be observed. Therefore, further research must be performed, focusing on this subject.

\section{Second experimental section}

The recovery yields were $75.95 \%( \pm 5.13)$ and $91.60 \%$ $( \pm 1.37)$ for the filtered and unfiltered samples, respectively. Regarding the filtered samples, the average concentrations of DEHP at the inflow and outflow points were 8.29 and $6.01 \mathrm{mg} \mathrm{L}^{-1}$, respectively. For the unfiltered samples the average concentrations were 41.61 and $17.04 \mathrm{mg} \mathrm{L}^{-1}$ respectively. The limit of quantification was $1.0 \mathrm{mg} \mathrm{L}^{-1}$. Figure 6 shows the DEHP concentrations in the unfiltered and filtered samples.

The results shown in Figure 6 suggest that the prefiltration step can influence negatively the amount of the extracted DEHP. Since DEHP has low water solubility (Table 1) a high adsorption of this chemical to
Unfiltered samples

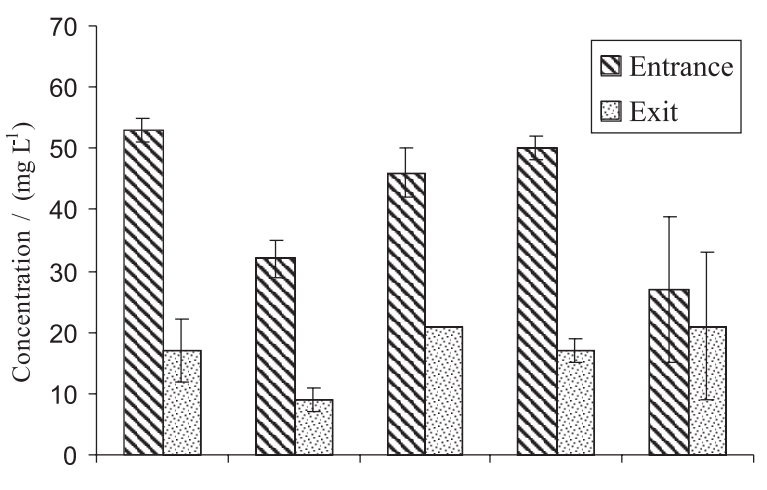

Filtered samples

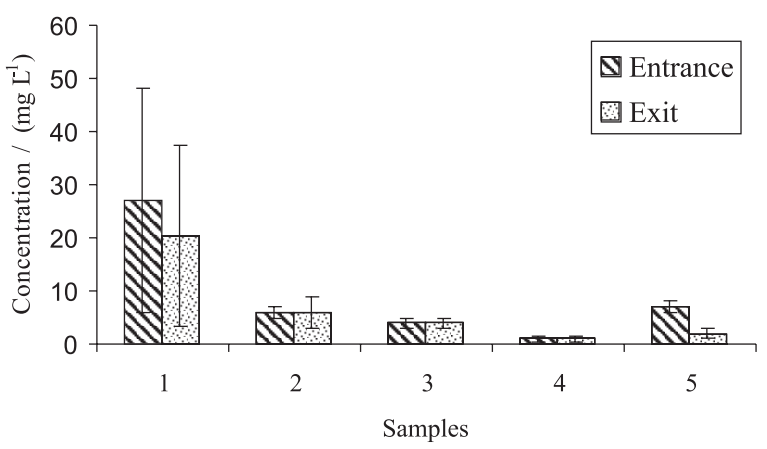

Figure 6. DEHP concentrations in the unfiltered and filtered samples. Error bars represent \pm standard deviations.

the surface of the suspended solid particles and organic matter must be expected. In this way, the prefiltration step can remove an important fraction of the contaminant from the sample, before the extraction procedure starting. Figure 7 shows that, 80.07 and $64.75 \%$ of the DEHP contained in the inflow and outflow samples, respectively,
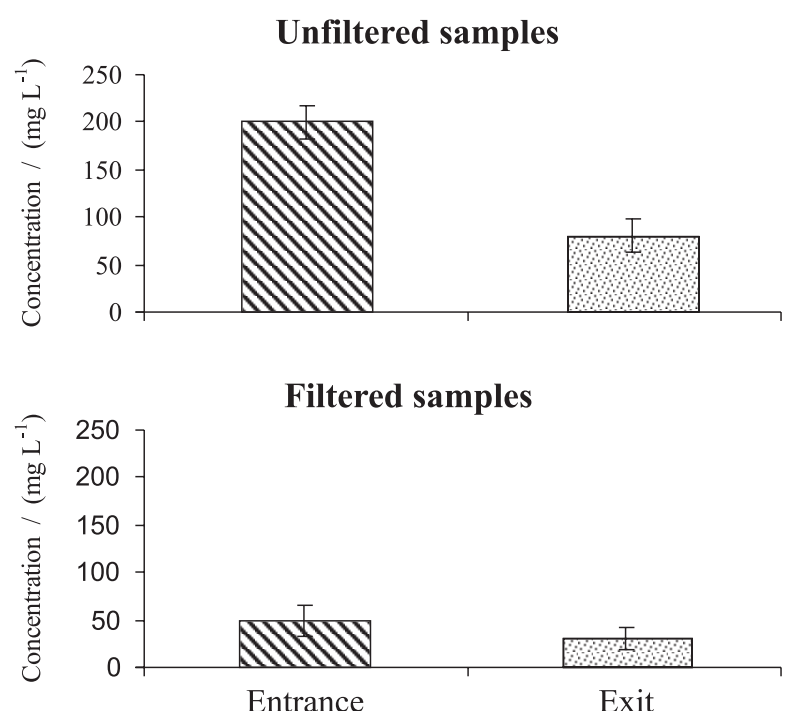

Figure 7. Mean concentrations of DEHP of the unfiltered and filtered samples at the inflow and outflow points. Error bars represent \pm standard deviations. 
were retained in the pre-filtration step (i.e. the suspended solids fraction).

The sources of the target compounds in the WWTPUCS may be cleaning agents used in the laboratories (floor or furniture cleaning, glassware cleaning, etc.), personal hygiene materials (like soaps, handcreams and cosmetics that often contain phthalates) and chemical residues form the laboratories. If plasticizers are part of a plastic matrix, they could be expected to be unavailable for biodegradation. ${ }^{21}$

\section{Conclusions}

The amounts of plasticizers in the inflow and outflow samples exceed the limit allowed by official regulators, such as US-EPA, and this may be due to the physicochemical characteristics of the sample, mainly suspended solids. The results suggest that more attention must be paid to the removal of the suspended solids as a way to reduce the amounts of the target compounds in wastewater treatment plants. Additional treatment (such as advanced oxidation processes or flocculation) may minimize the amounts of the target compounds in the effluent.

Our next steps will be to evaluate how the organic matter content can affect the plasticizers partitioning in the studied samples, additional treatments to reduce the contaminants concentrations and develop new studies for the identification of the plasticizers sources.

\section{Acknowledgments}

The authors thank the Conselho Nacional de Desenvolvimento Científico e Tecnológico (CNPq) and the Universidade de Caxias do Sul.

\section{References}

1. Nelson, P.; Occup. Environ. Med. 2003, 60, 541.

2. Mantovani, A.; Chemosphere 1999, 39, 1293.

3. Gray, J. R.; J. Clin. Oncol. 2002, 20, 4129.

4. Bornehag, C.; Sundell, J.; Weschler, C. J.; Sigsgaard, T.; Lundgren, B.; Hasselgren, M.; Hägerhed-Engman, L.; Environ. Health Perspect. 2004, 112, 1393.

5. Colón, I.; Caro, D.; Bourdony, C.J.; Rosario O.; Environ. Health Perspect. 2000, 108, 895.

6. Möder, M.; Popp, P.; Pawliszyn, J.; J. Microcol. Sep. 1998, 10, 225.

7. Bauer, M. J.; Herrmann, R.; Sci. Total Environ. 1997, $208,49$.

8. Akon, H.; Yoon B.; Takayuki, K.; Mariko, H.; Maya, M.; Takashi, N.; J. Appl. Polym. Sci. 2004, 94, 1737.

9. Gonzalez-Vila, F. J.; Saiz-Jimenez, C.; Martin F.; J. Environ. Qual. 1982, 11, 251.
10. Boyd, S. A.; Sommers, L. E.; Nelson, D. W.; Soil Sci. Soc. Am. J. 1979, 43, 893.

11. Nascimento, I. F.; von Muhlen, C.; Schossler, P.; Caramão, E. B.; Chemosphere 2003, 50, 657.

12. Aguilar, C. P.; Peruzzolo, M.; Di Luccio, M.; Dallago, R. M.; Nascimento, I. F.; Environ. Monit. Assess. 2006, 116, 103.

13. Yamamoto, T.; Yasuhara, A.; Shiraishi, H.; Nakasugi, O.; Chemosphere 2001, 42, 415.

14. Li, J.; Zhou, B.; Liu, Y.; Yang, Q.; Cai, W.; J. Hazard. Mater. 2008, 151, 389.

15. Forbes, V. E.; Selcka, H.; Palmqvista, A.; Aufderheide, J.; Warbritton, R.; Poundsc, R.; Thompson, N.; Hoeven, N.; Caspers, N.; Ecotoxicol. Environ. Saf. 2007, 66, 309.

16. Baird, C.; Environmental Chemistry, Freeman and Company: New York, 1999.

17. Huang, Q. G. W. J. W.; Environ. Sci. Technol. 2005, 395, 6029.

18. Suzuki, N.; Hattori A.; Life Sci. 2003, 73, 2237.

19. Zalko, D.; Jacques, C.; Duplan, H.; Bruel, S.; Perdu, E.; Chemosphere 2010, doi:10.1016/j.chemosphere.2010.09.058.

20. Braun, J. M.; Kalkbrenner, A. E.; Calafat, A. M.; Bernert, J. T.; Ye, X.; Silva, M. J.; Barr, D. B.; Sathyanarayana, S.; Lanphear, B. P.; Environ. Health Perspect. 2010, 119, 131. doi: 10.1289/ ehp. 1002366.

21. Staples, C. A.; Peterson, D. R. In The Handbook of Environmental Chemistry; Charles, A. S., ed.; Springer: New York, 2003.

22. Wintgens, T.; Gallenkemper, M.; Melin, T.; Water Sci. Technol. 2004, 50, 1 .

23. Fernandez, M. P.; Noguerol, T.; Lacorte, S.; Buchanan, I.; Piña B.; Anal. Bioanal. Chem. 2008, 393, 957.

24. Fauser, P.; Vikelsoe, J.; Sorensen, P. B.; Carlsen, L.; Water Res. 2003, 37, 1288.

25. Zheng, Z.; He, P.; Shao, L.; Lee, D.; Water Res. 2007, 41, 4696.

26. Zhang, C.; Huang, G.; Yu, J.; Wang, Q.; Li, J.; Xi, B.; Liu, H.; Chemosphere 2006, 65, 1490.

27. Cousins, I. T.; Mackay, D.; Parkerton, T. F. In The Handbook of Environmental Chemistry; Charles, A. S., ed.; Springer: New York, 2003.

28. Marttinen, S. K.; Kettunen, R. H.; Sormunen, K. M.; Rintala, J. A.; Water Res. 2003, 37, 1385.

29. Oliver, R.; May, E.; Williams, J.; Water Res. 2005, 39, 4436.

30. Clara, M.; Windhofer, G.; Hartl, W.; Braun, K.; Simon, M.; Gans, O.; Scheffknecht C.; Chovanec, A.; Chemosphere 2010, 78, 1078 .

31. Sirivithayapakorn, S.; Thuyviang, K.; Bull. Environ. Contam. Toxicol. 2010, 84, 503.

Submitted: November 26, 2010

Published online: February 22, 2011 